\title{
AN OUTLINE OF THE PANEL DISCUSSION ON "EXPROPRIATION PROCEDURE AND COMPENSATION" AT THE 1961 ANNUAL MEETING OF THE LAW SOCIETY OF ALBERTA*
}

\section{Introduction}

The power of expropriation, or compulsory purchase or eminent domain, is recognized in every state; and in Canada today it is exercised on a wide scale. Kighways, airports, public buildings, power lines, pipe lines and even universities are examples. The difficulty of fixing compensation is not new, but the amount and value of properties taken is probably greater than ever before. The first Canadian book on the subject by Mr. Justice Challies of the Superior Court of Quebec, appeared not long ago. The law reports abound with cases applying the "elusive concept" of value. Phrases such as-due compensation, market value, fair actual value, value to the owner, special adaptability, potentiality and incidental damages appear over and over again.

In Ontario the subject has become so politically important that the legislature set up a select committee of eleven members, with the present president of the Canadian Bar Association as counsel. It has been active for almost two years, holding public hearings, studying scores of briefs and visiting various provinces and states. Its report will probably be presented soon. British Columbia, with an experience of very large awards, appointed the Honourable Mr. Clyne as a one-man Commission over a year ago. He has not yet reported. The Department of Justice at Ottawa has been studying the federal law for some time and a new Expropriation Act is being prepared.

In this province the Copithorne' case drew public attention to the subject. This was not a dispute over amount, but over the right of the owner to be heard in opposition to the expropriation. Doubtless this case was a main reason why our new Expropriation Procedure Act ${ }^{2}$ was passed in 1961 with its separate provisions for taking by (1) the Crown, (2) Municipalities, (3) Companies, and (4) other bodies.

In the meantime important decisions have appeared in connection with the amount of compensation. For years the President of the Exchequer Court held that value means market value and also that a percentage should not be added. After the Woods' decision in 1951, it was clear that the Supreme Court thought him wrong-that value means value to the owner and that normally the $10 \%$ should be added. The

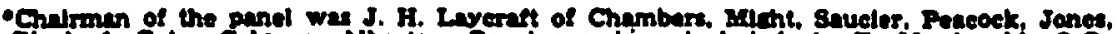

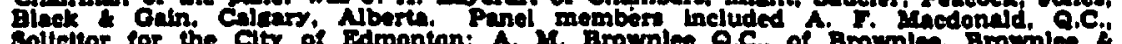

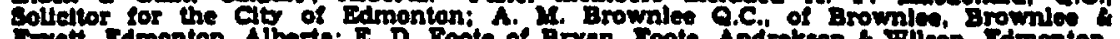

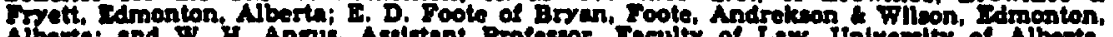

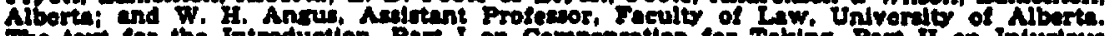
Trorta for tho introduction. Part I on Compeninton for Taking Pert it on injurtous

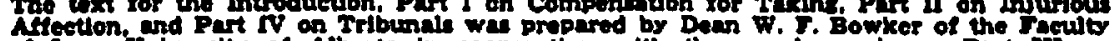

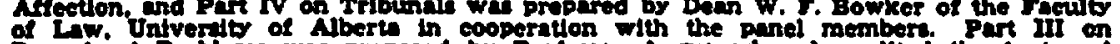
Procedural Problems was prepared by Protenor Angus who also edited the text and commentary lor publication.

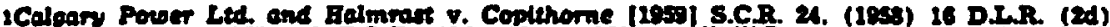

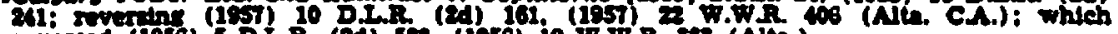
reverned (105) 5 D.LR. (2d) 500 , (1958) is W.W.B. 303 (Alta.).

rst. Ale. 18at, c. 20 .

IWood Manufacturing Co. Led. v. The Qmaen [195I] S.C.R. 504. [1951] 2 D.L.R. 465. (1951) 67 C.R.T.C. \& (B.C.C.). 
President in Sisters of Providencet in 1952 and Supertest" in 1954 bowed, while insisting that the Supreme Court judgments laid down conflicting tests, that he could not apply the Woods test and that the basis for adding a percentage was not clear. Then in 1959 our Appellate Division in the St. Mary case applied the $10 \%$, thinking the law settled. In June 1961, the Supreme Court held that, save in exceptional cases, it should not be allowed and that where allowable, it was for the disturbance and not merely because of difficulty in determining the value. The case was Drew v. The Queen: where the Dominion Crown took land for Malton Airport. At about the same time, the City of Toronto took land a few miles away and belonging to the Old Mill Restaurant. Scarcely was the ink dry on the Drew judgment when the Court of Appeal of Ontario allowed the $10 \%$ to the owners of the Old Mill in Valley Improvement v. Metropolitan Toronto."

In the light of all these facts the subject is timely. Professor Todd of the University of British Columbia has just written an article on the subject in the December issue of the Canadian Bar Reviewo dealing with much the same questions we are to consider today. We shall discuss two topies of substantive law and two of procedure. The four are:

(1) compensation for the taking

(2) compensation for injurious affection

(3) procedure, especially notice to the owner

(4) the tribunal

In all of them we shall examine the provisions and effect of the 1961 Alberta Act." ${ }^{10}$

\section{I}

\section{COMPENSATION FOR TAKING}

Many statutes use a general term to indicate the basis of the awarddue compensation, value of the land, fair actual value of the land. The federal Bxpropriation Act" under which most of the leading cases have been decided gives no detailed guidance.

Our Surveys and Expropriation Act ${ }^{12}$ specified (1) value of the land, (2) damage to remaining property, and (3) extra fencing. Manitoba's's is much the same, but ours is replaced by the new Act. The English Act of $1919^{\prime \prime}$ goes into considerable detail as to what is and is not allowable; likewise a draft prepared by the Ontario branch of the

\footnotetext{
tThe Queen v. Siters of Charity of Providence [1032] Lx. C.R. 113, [1958] 3 D.L.R. a58 (as.).

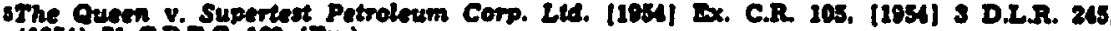
(105) 72 C.Rir.c. 169 (Ix.).

oRe SL Mary and Muk Rlvere Development and Hurrey (1959) 21 D.L.R. (2d) 209, (1959)

23 W.T.R. (A)te. CA.).

i[1981) 8.C.R. 614, (1961) 20 D.J.R. (2d) 124 (8.C.C.).

valley Improvement Co. Lud. Hetropollian Toronco and Reoton Conservation Authortty (1081) 2 D.L.R. (2d) 59s. (1961) O.R. 793 (Ont. C.A.), in a more recent dectalon. Re Samuel. Son \& Co. Led. and Munietpality of Hetropotien Toronto (1962) 22 D.I.R. (2d)

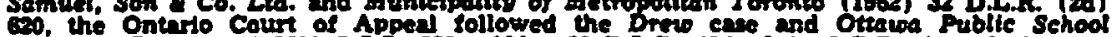
Bosed v. Compten [1961] S.C.R. 603, (1961) 89 D.LR. (2d) 213 (S.C.C.) in retusine the allowance of $10 \%$ for forctble takins.

DE. C. E. Todd, Wind of Change and the Law of Expropriation (1981) 29 Can. Bar. Rev. 342.

108t. Alta. 1861, e. 20.

11 R.S.C. 1952, c. 106.

12R.8A. 2985, c. 328, s. $19(1)$.

18The Exproprtatton Act, R.S.M. 19S4, c. 78, s. 65(1).

1tThe Acquialtion of Land (Ascesunent of Componention) Act, 1919 ( 8 \& 10 Geo. 8, c. 87).
} 
Canadian Bar Association. Some American statutes (e.g. Wisconsin's) 80 into miunte particulars.

Our 1961 Act provides:

Crown-due compensation for damages necessarily resulting.

Municipalities-The "due compensation" sections in the City Act" and Town and Village Act" are preserved but the "value" section of the Municipal District Acts is repealed and not replaced by any new provision.

Companies and other bodies-Formerly various statutes used different phrases-e.g., "fair and reasonable" in the Water, Gas, Electric and Telephone Companies Act" before 1956, "value of the land" in the Irrigation Districts Act,20 and "fair actual value" in the School Act.21 These and various others are repealed by the new Act and not replaced by a new criterion. Thus the general principles laid down by the Supreme Court of Canada are relevant here as the St. Mary"s case shows.

Question No. 1:

The present test of value includes special adaptability by the owner ("value to the owner") and may result in higher awards than a market value test. Which do you think is sounder?

MR. FOOTE: To the extent that "special adaptability" means "potential use" I believe market value usually reflects "special adaptability". However, if the property has a "special adaptability" unique to the owner because it forms part of a unit (e.g., space for the expansion of an existing plant), then it would probably have a value greater to the owner than it would in the open market. I favour the inclusion of "special adaptability" in establishing awards.

MR. BROWNLEE: If "special adaptability by the owner" causes the value to exceed "market value", he should be compensated accordingly. To rule otherwise would defeat the basic principle of due compensation.

MR. MACDONAID: The market value test is much the better yardstick of "value" in most cases. Value to the owner should not mean value to the particular owner but value to any owner who might acquire the land for its highest and best use.

PROFESSOR ANGUS: It seems to me that "value to the owner" is the fairer test, and therefore the sounder, as it takes into account the individual circumstances of the expropriated party. This approach is more consistent with a concept of compensation, in my opinion, than the more objective and impersonal "market value" test. "Market value" also presupposes the existence of a willing seller which is rarely the case in expropriations.

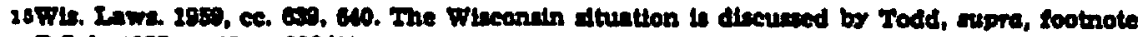
30R.8.A. 1935, c. 42, s. 200(1).

17R.s.A. 195, c. 200, a. $204(1)$.

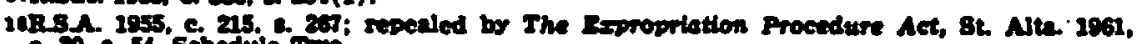
c. 00, 2. 34. Sohedule Two.

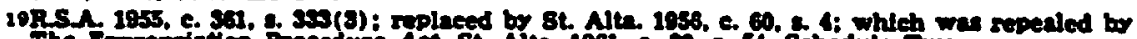

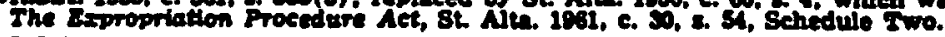

20R.SA. 2055, c. 102, a. 208 (10) (a).

21R.8.A. 1055, c. $207,2.218$ (1).

assupre, sootmole 6. 
Question No. 2:

What is the true basis of the $10 \%$ allowance-is it uncertainty and difficulty in fixing the amount, or is it compensation for compulsory taking, or for disturbance?

MR. LAYCRAFT: The chairman on a panel such as this one is supposed to keep out of the discussion, but I can't resist a comment on this question. From time to time in the field of expropriation one sees the tribunal, charged with the task of fixing compensation, shrinking from its duty by means of some arbitrary formula such as this $10 \%$ allowance. However difficult its task may be, the tribunal should face it without using a crutch. The fact that the allowance is merely a small $10 \%$ makes no difference. The same principle would be involved if the allowance were an additional $100 \%$.

PROFISSOR ANGUS: Uncertainty and difficulty in fixing the amount of compensation would appear to be the chief reason for the $10 \%$ allowance. Rather than permit the possibility of an expropriated landowner being short changed, $10 \%$ is added as a reasonable margin of error. Disturbance is another factor which undoubtedly accompanies an expropriation but it is difficult to measure in monetary terms. "Compensation for compulsory taking" on the other hand is a vague and more difficult notion although it probably is another consideration upon which the additional 10\% is based. Although the $10 \%$ allowance is much criticized, I believe that in many cases it compensates for matters not included within the "value to the owner" formula and is therefore justified in the absence of a better measure.

MR. MACDONALD: The Drew ${ }^{22}$ case points out how confused judicial thinking has been on this matter and Judson J. implies that the $10 \%$ practice has been a convenient but mistaken way to give "something extra". Many of the older cases were decided with incomplete appraisal evidence on expropriation "value" and where that happened probably the judge took the easy way out wishing to err on the side of generosity to the man whose land was taken in the absence of satisfactory evidence of "value".

MR. BROWNLEE: The $10 \%$ allowance compensates for factors of value to the owner which are incapable of accurate evaluation. In my opinion, there should be no compensation paid because of the element of compulsory taking itself.

MR FOOTE: Who is to say? In the case of Irving Oil Company v. The King," $10 \%$ was added by the Supreme Court of Canada to resolve uncertainty. And in the Exchequer Court case of The King v. Berger, as it was added for disturbance on loss of business consequent in compulsory taking.

Question No. 3:

Do you think that "value to the owner" plus a percentage allowance put an undue burden on the public purse as Thorson P. does?

assupre, sootnote 7.

s[1946] 8.C.R. BLI, [1946) \& D.L.R. 605, (1946) 60 C.R.T.C. 200 (S.C.C.).

23[1951] Ex. C.R. 205 (20x.). 
MR. BROWNLEE: I do not think that the "undue burden" argument justifies basing compensation on "market value" rather than "value to the owner".

MR MACDONALD: Yes. If "value to the owner" is correctly applied, a percentage allowance is seldom warranted and its semi-routine use is an undue burden on the public purse.

PROFESSOR ANGUS: The public purse must be prepared to pay fair and reasonable compensation to expropriated landowners. In my opinion, "value to the owner" and a 10\% allowance are fair and reasonable in many expropriation proceedings for the reasons given in my answers to the previous two questions, and do not put an "undue burden" on the public purse.

MR. FOOTE: I don't believe that in establishing compensation we should concern ourselves with the burden on the public purse. I think we should simply concern ourselves with whether the owner whose property has been expropriated has been adequately compensated. In my view if the owner is compensated on the besis of "value to the owner", be will be adequately compensated (i.e., it will reflect any element of disturbance) and there can be no justification for adding a percentage allowance.

\section{Question No. 4:}

Should an expropriation statute give only vague guides as ours does or should it go into detail?

MR. BROWNLEE: So long as determination of compensation is by a competent and experienced authority, I would not favour an attempt to spell out the items of compensation to be considered in every case, for fear of creating confusion and uncertainty.

MR. FOOTE: I'm afraid of a detailed formula for fixing compensation, especially if it should have the effect of artificially restricting the amount of the awards, with the result that an owner is not compensated on the "value to the owrer" concept. It may be that our case law in its development has adopted some artificial or confused rules relating to the addition of a percentage allowance or the application of the principle of injurious affection. We might profitably resolve one or two of these items which on the basis of the decision are still a source of much confusion, by statute.

MR. MACDONALD: A set of statutory rules to determine "value" would provide years of frustrating litigation as to the meaning of the statutory language. Anyway, arriving at "value" for a complete taking is not that difficult. Also, the rules that fit a complete taking are perhaps only confusing where a partial taking is the issue. Again, the rules fit most ceses but fail to cover cases with difficult facts such as were found in the Woods"s case and the Sisters of Charity" case.

PROFESSOR ANGUS: When one observes the confusion currently prevailing in our courts on the proper measure of compensation, it is abundantly clear that a statutory guide is very much needed. The 
English Act of $1919^{28}$ illustrates the point. It provided, for example, that "market value" was to be the accepted standard and that no allowance could be made for the element of compulsory taking. Whether or not you agree with these directions, they employ clear and precise language which does not permit deviation into uncharted waters. In England as a result, problems concerning the measure of compensation have been largely overcome.

II

\section{INJURIOUS AFFECTION}

Expropriation statutes usually provide that a person shall be compensated where lands are not taken, but are reduced in value (injuriously affected) by an expropriation.

Where part of the claimant's land has been expropriated, the value of what is left may be reduced. Thus in the St. Mary ${ }^{29}$ case, the expropriation for a dam took some four sections of a ranch containing 400 sections. The part taken was the beart of the ranch, providing water and winter shelter, so its loss reduced the value of the huge area that was left. Our Appellate Division upheld an award of $\$ 76,000$ for the land taken and $\$ 50,000$ for injurious affection to the balance. All allowed 10\% more on the first figure but a 3-2 majority refused to add it to the $\$ 50,000$ for injurious affection. (Flad the Drew" case been decided, it is doubtful whether a percentage would have been added even to the compensation for land taken.)

The basis of compensation for injurious affection is not spelled out in detail. Where part of a parcel of land is taken, and a claim is made for injurious affection to the balance, Challies says the claimant must show that:

(1) the affected lands were beld with the land taken,

(2) the damage has arisen from acts done in the land taken, and

(3) the damage must not be too remote.

When this is shown, the claimant is entitied to compensation for loss of business and for injury due to operation as well as construction of the work, according to Anglin J. in C.P.R. v. Albin," a 1919 decision of the Supreme Court of Canada.

If no property is taken, it is still possible to claim, but the basis of the award is much lower. In the typical case, a road or railway runs near the land and alters the grade so that access to the claimant's property is rendered difficult. Although the Railway Act prescribes full compensation, it is settled that a claimant can get compensation only for reduction in market value and not for loss of profits (C.P.R. v. Albin, rupra). In Autographic Register v. C.N.R."2 in the Exchequer Court in 1933 , the railway had built a subway and the claimant alleged serious depreciation to the value of its building, claiming $\$ 50,000$. It was found that in many ways the subway improved the value and that the only

acsupre, sootnote 14.

30Supre, tootnote 6.

sosture, sootnote 7 .

a1(1919) 59 8.C.R. 81. (1919) 49 D.L.R. 619, |1919) 3 W.W.R. 873 (S.C.C.).

sग|18s9| In. C.R. 152 (Ex.). 
loss was of publicity (a sign became obscured) and slight difficulty of access. Angers J. awarded $\$ 1,200$. He laid down these rules:

(1) The damage must be for an act rendered lawful by the statutory powers.

(2) The damage must be such as would be actionable at common law

(3) The damage must be an injury to the land itself and not to business and (or) trade.

(4) The damage must be occasioned by the construction of the work, and not its uses.

In other words, the exercise of statutory powers may expose property owners to various types of loss that are not compensable.

This fact renders all the more significant the following amendment made in $\mathbf{1 9 6 0}$ to the City Act:

303a. Notwithstanding any other provision of this Act, where in the exercise by a city of any of the powers conferred on it by this Act the city, in the erection or construction of a city.work or structure, causes damage to an owner or other person having an interest in land immediately adjacent to the land upon which the city erects or constructs the work or structure by reason of loss of or permanent lessening of use of the land of that owner or other person, the person sustaining the damage is entitled to compensation therefore and may, at any time after the damage has been sustained and within sixty days after notice has been given in a newspaper of the completion of the work or structure in respect of which the damage is sustained, file with the city clerk a claim for damages in respect thereof, stating the amount and particulars of his claim.

[Compare sec. 299(1).] Section 303a is now under consideration by Milvain J. in connection with a claim for injurious affection in relation to the 105th St. overpass in Edmonton.

The 1961 Act deals with injurious affection as follows:

Crown-An owner of land that is injuriously affected is entitled to due compensation for damages necessarily resulting. (s. 15: also 16 and 18)

Municipalities-Sections 27 and 28 set out the procedure in claims for injurious affection; the City Acts [s. 299 (1)] and the Town and Village Actst [s. 284 (1)] provide for due compensation, in terms similar to section 15; the Municipal District Act"3 does not. [Section 267 (1) repealed by the new Act did contemplate compensation where part of the owner's land was expropriated but not where no part was.] At the same time, section 309 (c) of the City Act still provides for arbitration of a claim for damages incurred by reason of the loss of or lessening of the use of land, by either a Supreme Court judge, District Court judge, or a barrister.

Companies and other Bodies-There is no mention of injurious affection but section 35 (2) (e) requires the Public Utilities Board to find the amount payable for incidental damages resulting or likely to result from the construction of the work. 
Question No. 5:

Do you think the judge made rules as to basis of compensatiton (a) where some land is taken, (b) where no land is taken, are sound?

MR. MACDONALD: They are "sound" in the sense that they keep injurious affection cases confined to damage to the land as distinct from loss to the business conducted on the land. However, this principle is hard to reconcile with the "value to the owner" concept.

MR. BROWNIEE: I do not feel that the judge made rules are sound, and I think that Anglin, $J$. in the Albin case took the same view. It does not seem reasonable to me that the owner of land taken who has also suffered injurious affection should be able to claim for loss of goodwill and business, while another owner who suffers injurious affection without having land taken should be restricted to a claim for lessening of the value of his land.

PROFESSOR ANGUS: It is clear that compensation should be awarded in both situations under proper circumstances. However, it is difficult to see why the basis for awarding compensation in the two situations should be different where the nature of the damage is the same. In this respect, the rules for recovery of compensation where no land is taken would seem to be too narrow and restrictive. At the same time, most everyone would agree that there should be some limitations on liability. One is forced to conclude that the judge made rules are in need of reconsideration.

MR. FOOTE: No, I do not! In my view "injurious affection" is an unnecessary and hybrid development of the law, which is full of artificial rules, and produces inconsistencies and inequities. It purports to provide compensation for the following items:

(a) diminution in value of land by reason of severance or amputation (e.g., the St. Mary" case. This item of damage could just as well be left as a factor in arriving at "value to the owner" without setting up a separate head of damages under the heading "injurious affection".),

(b) damage to the owner by reason of the use to which the expropriated land is put (This applies only in the case of an owner part of whose land is taken and even though the use would not have been actionable at common law.), and

(c) diminution of the value of land by reason of the construction of works if such construction would have been actionable at common law, e.g., a public nuisance, interference with access, vibration, noise, smoke, etc. (This has nothing to do with the law of expropriation and proceeds on entirely distinct principles of common law.)

It is difficult to justify the distinction made in paragraph (b), i.e, damages to an Owner $A$ who has had a portion of his land taken, and no damages to Owner $B$ who has had none taken, if for example the land taken from A was only a splinter to widen a railroad right of way when in fact the construction and use of the right of way for a railroad causes equal damage to $A$ and $B$ who both own land adjoining the right of

3asupre, sootnote 6. 
way. In applying paragraph (c), the Courts have held that once I prove that the construction as distinct from the use is actionable at common law, then I'm entitled to recover damages based on the use being made of the property even though the use is not actionable.27 Since in the new Expropriation Procedure Act a claim for "injurious affection" is limited to those cases where land has been expropriated, it might be implied that no claim for injurious affection would lie with Owner B if works which constitute a public nuisance were constructed on land acquired from Owner A by negotiation without recourse to expropriation.

Question No. 6:

In the new Act "due compensation" is to be given for injurious affection at least in the case of the Crown, Cities, Towns and Villages. Does this phrase embody the judge made rules mentioned in Question No. 5 ?

PROFESSOR ANGUS: Although the way is open for a creative court to break new ground in determining the meaning of "due compensation" under the new Act, and I hope that one will take up the challenge, it would seem more realistic to expect that this phrase will be interpreted in the light of the judge made sules which are at best familiar.

MR. MACDONALD: As "due compensation" has been interpreted in such Ontario cases as Re Conger Lehigh and Toronto," the judge made sules are upheld completely.

MR. FOOTE: I am of the opinion that "due compensation" must be interpreted in accordance with the common law rules.

MR. BROWNLEE: Section 15 of the new Act seems to go farther than the judge made rules in that a landowner who has not been subject to expropriation but whose land has been injuriously affected by an expropriation is entitled to "due compensation for any damages neces. sarily resulting from the exercise of the power of expropriation ..." This could include loss of profits, etc., and is therefore an extension of the judge made rules.

Question No. 7:

Does the obligation of companies and other bodies to pay for "incidental damages" cover injurious affection? To what extent?

MR. FOOTE: In my opinion, the omission of any reference to "injurious affection" in the provisions relating to companies does not absolve a company from liability for payment under that heading of damages. If anything, the wording is broader than the common law limitations on assessing damages. I favour retention of the common law position however.

MR. MACDONALD: It is doubtful whether injurious affection is covered by the term "incidental damages". If it is not, the result is unfair in that all bodies should surely be subject to the same rules.

MR. BROWNLEE: I would interpret section 35(2) (e) as including injurious affection. The words ". . . incidental damages resulting from

siCorporatton of the City of Toronto y. J. P. Brown Compony (1917) 35 S.C.R. 159, (1017)

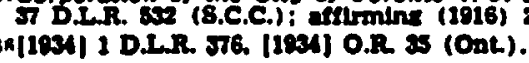


or likely to result from the construction of the works ..." are sufficiently inclusive.

PROFISSOR ANGUS: "Incidental damages" are limited by section 35 (2) (e) of the new Act to those "resulting from or likely to result from the construction of the works". This limitation is the same imposed by case law where the party injuriously affected has no land actually taken. Section 35 (2) (e) does not permit recovery for damage occasioned by uses of the land expropriated and therefore it does not cover injurious affection to the extent envisaged by the Albin ${ }^{30}$ case where the injured party is also the person expropriated. In this respect then, the new Act is much narrower than the common law and, I would suggest, is most inadequate.

Question No. 8:

(4) What is the effect of sec. $303 a$ of the City Act ${ }^{\text {sn }}$ on the judge made rules? Is this good?

MR. MACDONAID: There is no language in any Canadian statute like the language in the City Act of section 303a. There are no cases where the measure of "value to the owner" has been applied to injurious affection. The case law to date holds that value in such cases is the value of the property "as a marketable article employed for any purpose to which it may legitimately and reasonably be put". To change this judge made rule would increase greatly the cost of overpasses, underpasses, etc. built on public highways for the use of the motoring public.

PROEESSOR ANGUS: Liability of a city for injurious affection is clearly and considerably extended by section 303a. Its operation is not limited to expropriation situations and would seem to place a greater burden upon a city than is otherwise placed upon a private property owner. It is obviously discriminatory unless it can be argued that every property owner should be placed in a similar position.

MR. BROWNLHE: Section 303a of the City Act is, again, an extension of the judge made rules. It does not go as far as section 15 of The Expropriation Procedure Act as it is restricted to damages to land immediately adjecent to the land upon which work is constructed. I think it is probably good.

MR. FOOTE: Section 303a to my mind is far too great an extension of the common law rules. This section would support claims resulting from the conversion of a highway to a one way street. One might then wonder whether rerouting of highways shouldn't give rise to compensation claims. Where should it stop?

DI

\section{PROCEDURAL PROBLWMS}

The main lssue in this area lies in the question of notice and a hearing to a landowner prior to the actual expropriation of his land. A landowner is not entitled to either notice or a hearing unless the authorizing statute expressly requires them, or it is deemed that "natural justice" must be observed by a person or body found to have a duty to act "judicially". 
Earlier English expropriation statutes did not demand notice or a hearing but more recent enactments such as the Town and Country Planning Act, 1947' do. Despite the "due process" requirement in the Fourteenth Amendment to the U.S. Constitution," the Supreme Court of the United States has twice affirmed that expropriation is a legislative question in which notice and a hearing are not essential. ${ }^{18}$ Most U.S. statutes now expressly require notice and a hearing prior to expropriation however." The Canadian position past and present generally resembles the earlier English view that one's remedy lies in compensation and thus a hearing prior to the compulsory taking is unnecessary.

The Expropriation Procedure Acts passed at the last session of the Alberta Legislature can probably be attributed to the leading case of Calgary Power Limited v. Copithorne." Calgary Power was unable to obtain a right of way over Copithorne's land and therefore made an ex parte application for an expropriation order under The Water Resources Act' to the Minister of Agriculture who issued the order without notice of the application or a hearing to Copithorne. The Supreme Court of Canada reversed the majority judgment of the Appellate Division, characterizing the Minister's actions as "administrative" in nature to which the requirements of natural justice as to notice and a hearing did not apply.

The Water Resources Act was amended in 1956 to require the Minister to have regard to "the objection of an interested party", and the Expropriation Procedure Act followed. It categorizes expropriating bodies by type-that is, the Crown, municipalities, companies and "other bodies" - and prescribes a different procedure for each, except other bodies which are to be treated in the same way as companies.

\section{Question No. 9:}

Should a landowner be given notice and a hearing prior to the actual expropriation?

PROFESSOR ANGUS: To answer this question, one must determine whether notice and a hearing would serve a useful purpose. There would appear to be a number of legitimate issues which might be raised at an expropriation bearing, for example, whether the land is necessary for the public undertaking, whether an alternative route would be more satisfactory, or whether the proposed expropriation is within the terms of the statute. In addition, if a hearing is given, an expropriated party will have had his "day in court" rather than feel that the rug has been pulled out from under him. Notice and a hearing are fundamental to the administration of law and justice, and should be observed in every expropriation proceeding.

1110 \& 11 Cov. a. $\mathrm{s1}$.

-asoctlon 1 of the Eourtounth Amendment thates in part: ". . No State thall mike or

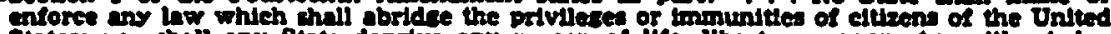

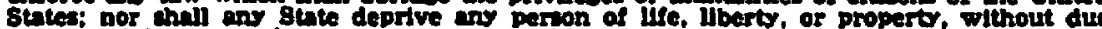
proces: of Lw: nor dent to any pereon within lts Juridedetion the equal protection of the laws."

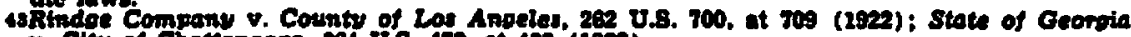
v. Clit of Chattanoona, 24 U.s. 472 . at 403 (IMa).

408 C.J.s. Aninent Damin 126 (1941).

4age. Alte. issi. e. 50 .

insugis, 200 thote 1.

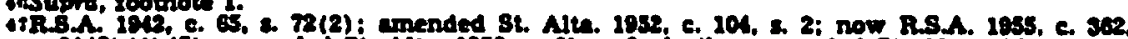
4. H(a) (1) (5): amended st. Alen. 1956. c. 61, 2. 9; turther amended 8t Alth. 1960, c. 115, B. 2: and BL. Nita, 1962, e. SO, E. BA, Behedule Two. 
MR. LAYCRAFT (Chairman): It seems to me that there is a practical difficulty in a hearing in which the landowner is entitled to contend that the utility should proceed across adjoining land. At the point where he suggests the name of the adjoining landowner, the hearing would of necessity be forced to adjourn until that landowner was served, and appeared to make his representations. If the second landowner in turn were to suggest the name of a third, still a further adjournment would be necessary. Thus, it seems to me that the hearing as a practical matter would have to be restricted to allowing changes only within the boundaries of the land in question.

MR. FOOTE: Ownership of property in our democratic society should still be sufficiently sacred that, before it is taken away from us, we should at least be notified concerning the intended taking and given an opportunity to appear before an impartial board to consider the advisability of the proposed route or location, the extent of the land required and in proper cases, the advisability of an alternate route or site. Expropriating authorities are not infallible in their decisions, such as choice of route, etc., and there may be important considerations disclosed in the submissions of affected landowners which could influence them to select an alternative route or site. Owners are presently denied this right of hearing under the new Act except in the case of expropriation by municipallities." And even there the right of the owner to be heard is a hollow one because later on in the Act, section 45 expressly provides that: "No person . . . may dispute the right of an expropriating authority to have recourse to expropriation or to question whether the land or estate or interest therein to be expropriated is necessary or essential for the public work ...". Iniquitous!

MR. MACDONAID: He must be told ahead of the taking but in view of the wording of section 45 of the new Act, there is no point in a hearing except to decide the award. Note that a different rule applies to cities alone and this is discriminatory.

\section{Question No. 10:}

Is it necessary and desirable to have three different procedures or would it be better to have (a) one uniform procedure, or (b) many different procedures, each tailored to the individual needs of a specific type of expropriation?

MR. FOOTE: I believe the principles involved are the same whether the expropriating body is the Crown, a municipality or a companyexpediency and public benefit on the one hand, and rights of the landowner on the other. For this reason, I would favour one uniform procedure which involves a preliminary "route or site hearing" at the option of the affected owners and a subsequent hearing, normally after construction of the works, to establish compensation.

IIR. MACDONALD: The Act should permit of eliminating the hearing and the advertisement if all that is in issue is quantum. There should be one procedure for contested taking and another for taking where only compensation is the issue. 
MR. BROWINLE: I think that the procedure should be uniform, and particularly so in respect of the right of landowners to be heard.

PROFESSOR ANGUS: In my opinion, a uniform procedure is highly desirable since it eliminates the confusion occasioned by different procedures. The issues involved are the same in all cases and the three separate procedures in our new Act would seem unwarranted.

\section{CROWN EXPROPRIATION}

Land becomes and is vested in the Crown upon registration in "the land registry" of a plan or notification [s. 10(1)]. No prior notice is necessary and no hearing in advance of the expropriation is required. The landowner is "entitled to due compensation" which, in the absence of agreement, is to be determined by arbitration under The Arbitration Act ${ }^{10}$ or, failing agreement on this procedure, by a judge of the Supreme Court.

\section{Question No. 11:}

Is the favourable position in which the Crown is placed warranted under modem conditions?

MR. BROWNLEE: No.

PROFESSOR ANGUS: The historical reasons for Crown privilege and immunity disappeared long ago. This is reflected in recent legislation such as The Proceedings Against the Crown Acts in this Province. If the Crown is to be subject to the same expropriation procedure as everyone else however, a quick and effective procedure must be provided to prevent undue delay of government works.

MR. MACDONALD: The Crown should have no different a position than the municipalities it creates.

MIR. FOOTE: In my opinion, the position of the Crown should parallel that of any other body to which the power of expropriation is given. Once the right of expropriation is given, the principles are the same.

\section{EXPROPRIATION BY MUNICIPAITITES}

The procedural requirements in this area have been changed somewhat. A municipality must serve a notice upon the landowner setting forth certain specified details relating to the expropriation including the date, time and place at which the by-law will be first presented to the municipal council, and advising that he is entitled "to make representations to the municipality and set forth his reasons why the land should not be expropriated" [s. 24 (2) ]. Section 25 (1) then provides that before enacting the expropriation by-law, a council shall have regard to (a) the recommendation of its departments or consultants, (b) "the objections of an interested party", and (c) "the needs and general good of the municipality". Compensation is to be determined by the Public Utilities Board if not mutually agreed upon by the parties.

Question No. 12:

Are the provisions in this part concerning a hearing adequate from the landowner's point of view? 
MR. MACDONAID: Except for a city, they are not adequate since section $45^{32}$ gives the owner a hearing but no rights at the hearing. He is limited to compensation which is not what the "hearing" deals withso the owner is frustrated, and his time and money are wasted.

MR. FOOTE: My comments on Question No. 9 apply here.

PROFLSSOR ANGUS: Although the landowner is given a hearing of a kind, it is in front of the party opposed in interest. It is obvious that "a reasonable apprehension of bias" will exist in his mind when the municipality is the judge in its own cause.

MR. BROWNLEH: In my view sections 24 and 25 of The Expropriation Procedure Act will result in trouble for municipalities and are of no value to landowners. After baving had plans of survey prepared delineating the route of a highway, municipalities must have a hearing for the landowners affected. Before passing an expropriation by-law, the council must have regard to the objection of the landowners who, by virture of section 45, cannot dispute the right to expropriate or whether the land to be expropriated is necessary for the public work. Such a hearing would in reality fail to accomplish much more than to give the landowner an opportunity to blow off steam. Furthermore it would make the passing of the expropriation by-law a quasi-judicial function (it being formerly a puraly administrative function), thus paving the way for attacks on such by-laws in the courts. I would suggest that when municipalities prepare and publish a wories programme and have determined, for example, the route of a highway, all landowners affected thereby should be notified, and a hearing should take place at which the landowners could comment on the route and state their objections. The municipal councils could then exercise their discretion and pass the necessary expropriation by-laws subsequently.

Question No. 13:

Are the provisions satisfactory from the municipality's viewpoint?

PRONDSSOR ANGUS: Obviously a municipality would prefer to avoid a hearing altogether. However, as the municipality is required to consider the objections of interested parties and presumably must act "judicially" in so doing, there arises the question whether the municipal council is capable of meeting the standards of "natural justice" in the light of the background and lack of legal training of its members. Perhaps on the other hand, municipal councils should familiarize themselves with the requirements of a fair hearing, and legal advice is certainly available to them in this regard.

MR. FOOTE: Again my remarks in answer to Question No. 9 pertain here.

MR. BROWNLFF: Likewise my comments on Question No. 12 cover the municapility's position.

MR. MACDONAID: They consume time to no purpose except when the "municipality" is a city," and so are unsatisfactory. Speaking for a City, I say the procedure is alright except when the parties have agreed

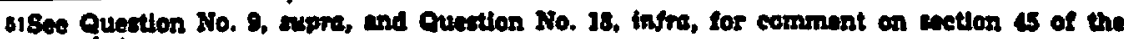
now Act.

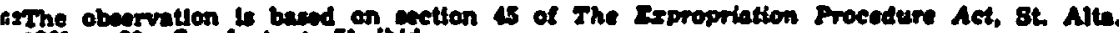
id61. c. 30 . 800 lootnole 51 , thid. 
to everything except the price, and in that case the preliminaries should be waived and the arbitration of compensation should be expedited.

\section{EXPROPRIATION BY COMPANISS}

Provision is made for application to the Public Utilities Board for an expropriation order. However this procedure does not affect the power of a Minister under an authorizing Act to preseribe the intended route of a company undertaking [s. $32(1)$ ]. When a permit is issued by a Minister authorizing the works of a company, the provisions of the authorizing Act wrill govern (s. 33). Thus in the Copithorness situation, a company would make application to the Minister for approval of the intended route of the right of way pursuant to s. 84 (b) (1) of The Water Resources Act. 30 The Water Resources Act then provides:

84d. (1) Upon receiving a certificate of approval from the Minister the Licensee may take and expropriate for the purpose of a right of way or site, as the case may be, so much of the lands or interest therein as may be approved by the Minister for the route or site.

(2) The manner in which and the terms upon which a licensee may exercise the right to take and expropriate any lands or any interest in lands ....

(b) in the absence of any such agreement shall be as set forth in The Expropriation Procedure Act.

It is clear that a company has "the right to take and expropriate" under the Water Resources Act prior to its application to the Public Utilities Board under The Expropriation Procedure Act, leaving only the "manner" and "terms" of the taking to be decided by the Public Utilities Board.

Where an application is made in the ordinary course of events to the Public Utilities Board, notice must be given by the company to interested parties. Provision is also made however for an interim order of expropriation "either ex parte or upon such notice ... as the Board in its sole discretion may direct" [s. 36(1)]. A deposit "may" be required by the Board in this event to secure the payment of compensation, and the interim order may be rescinded upon application or by the Board's own motion [s. 36 (1) (7)].

Question No. 14:

Would it be preferable to have an administrative tribunal decide all matters relating to the expropriation rather than make an exception for a Minister acting under a particular authorizing statute?

MR. BROWNLWHE: Yes. This should also lead to greater uniformity of awards.

MR. MACDONALD: I favor the Public Utilities Board acting in all cases as the tribunal.

PROFESSOR ANGUS: There is no valid reason why a competent administrative tribunal should not decide all matters relating to an expropriation and it would be infinitely better not to divide the responsibilities as certain authorizing statutes in this Province do.

sasupre, lootnote 1.

41R.S.A. 1955, C. 302, and amendments therels. See lootnate 47, sump. 
Question No. 15:

Are the landowner's interests sufficiently protected in the event of an ex parte interim order?

MR. FOOTE: Surely no landowners' interests can be sufficiently protected in the event of an ex parte interim order obtained by a company, permitting that company to exercise rights in or over the owner's land. A man can only be sufficiently protected if he is represented at a hearing.

MR. BROWNLEE: If landowners are to be permitted to complain with respect to compulsory taking, and I agree that they should be, they are not protected in the event of ex parte orders.

MR. MACDONAID: In practice they are, because the Board is careful with its practice rules to protect interested parties. The flaw is that the interim ex parte order, although available to a company, is only available to a municipality in the special case where it owns and operates a public utility.

PROFESSOR ANGUS: Once an ex parte order is granted, there is little possibility of it being rescinded where the expropriating authority has immediately commenced construction of the undertaking. As a result, the landowner's claim can effectively be reduced to ane of compensation only, without a hearing on the merits. Although this may not happen often, if ever, the possibility of abuse remains open.

Question No. 16:

If an exeditious procedure providing for notice to the landowner was available, would it be advisable to dispense with ex parte procedure?

MR. BROWNLIFE: Certainly.

MR. FOOTE: Yes!

MR. MACDONALD: This question 'begs the question' for the procedure is only invoked when absentee owners cannot readily be served. Courts do not abuse ex parte procedures, I think.

PROFESSOR ANGUS: There should be little, if any, necessity for resort to the ex parte procedure in the first place. Undertakings of the nature contemplated require considerable planning and do not become imperative overnight. So long as a speedy procedure providing for notice is available, it would not be unreasonable to dispense with the ex parte procedure and thereby preclude possible abuse.

\section{EXPROPRIATION BY OTHER BODIES}

This part of the new Act contains only two sections, one defining in a very general way the meaning of "authorized body", and the other stating that an authorized body may expropriate in the same manner as a company under Part III of the Act.

Question No. 17:

Might this part not better be incorporated into Part III by extending the definition section of that part as has been done in the Manitoba Expropriation Act.ss

MR. MACDONAID: Yes.

aAR.S.M. 1954, c. 78. 
MR. BROWNLEE: Yes. It would provide more uniformity.

PROFESSOR ANGUS: Although not of overwhelming importance, a merger with the company provisions would add to the uniformity of the Act.

MR. FOOTE: Agreed! - and then Part III might be incorporated into Part II and Part II incorporated into Part I, so that we end up with one uniform procedure.

\section{GENFRAL PROVISIONS}

Section 45 appears to be a most important provision:

45. Except as provided in subsection (5) of section 25, no person may in any proceedings under this Act dispute the right of an expropriating authority to have recourse to expropriation or question whether the land or estate or interest therein to be expropriated is necessary or essential for the public work or the works, as the case may be, for which it is to be scquired.

Section 25 (5) pertains to expropriation by a city pursuant to a plan of development where the "public interest" must be considered by the Board.

\section{Question No. 18:}

Does section 45 render the notice and hearing provisions of the Act illusory by removing the essential issues from consideration?

MR. FOOTI: Yes, for the reasons stated in my anwer to Question No 9.

MR. MACDONAID: Yes-except where cities are involved in a "plan of development" as this term is defined in section $298(2)$ of the City Act. ${ }^{\text {.0 }}$

MR. BROWNLEE: Yes. This anomaly was discussed in my response to Question No. 9.

PROFESSOR ANGUS: It appears to do so. One wonders why the Legislature went to such great lengths to provide various procedures and then remove from consideration the very issue to be resolved by these procedures. This is an iniquitous provision and I doubt that those responsible for the legislation appreciated its implications. It should be removed from the Act without delay.

\section{CONCLUDING RMMARIKS}

\section{Question No. 19:}

(1) Are the provisions of The Expropriation Procedure Act satisfactory? If not, what changes should be proposed?

MIR. FOOTE: Not really. All that the Act hos accomplished is to collect expropriation provisions as they relate to the Crown, municipalities, companies and other bodies into one Act. No attempt has been made to merge the procedures or even adopt a common nomenclature. I would favour a uniform procedure which provides for a preliminary "Route or Site Hearing" when requested by an affected owner.

PROFESSOR ANGUS: Obviously the provisions of the new Act are unsatisfactory in many respects. It is to be hoped that they will be

OAR.S.A. 1955, e. 4. 
reconsidered and amended at the earliest possible opportunity. Three major changes which, in my opinion, should be considered are:

(a) the establishment of a uniform procedure applicable to all expropriating bodies including the Crown, which provides for a hearing before the vesting of land in the taker,

(b) the appointment of an independent administrative tribunal to deal with expropriation matters only; and

(c) a specific statement in the Act as to the yardsticks to be employed in the measurement of compensation.

MR. BROWNLFr: They leave a great deal to be desired. I would suggest these changes:

(i) All awards of compensation should be made by one authority.

(ii) Notification to landowners of impending expropriations and hearings of the complaints of landowners should precede the meeting of municipal councils at which expropriation by-laws are to be proposed.

MR. MACDONALD: In my opinion also, they are not satisfactory and I would propose the following changes:

(1) The procedure should be alike for all bodies.

(2) There can be no valid reason for making cities subject to different substantive law provisions (Section 303a).

(3) The Act is not uniform on injurious affection rights.

(4) The Crown should be on the same basis as other takers or other 'injurious affectors' of property-both for procedure and for substantive rights.

(5) Arbitration as a mode of setting compensation is most unsatisfactory and should be scrapped.

(6) All bodies should have the issue of quantum put before the Public Utilities Board with an appeal to Courts on questions of law.

IV

\section{TRIBUNAIS}

From time to time there have been different tribunals in England, the United States, and under Dominion and provincial law. For example, under the Dominion Expropriation Act ${ }^{\text {s7 }}$ jurisdiction is in the Exchequer Court and under the Railway Act" in the provincial courts. In the United States, juries are still sometimes used. In England, the Lands Tribunal Act, $1949^{\circ}$ provides for a president with legal training and members who are lawyers or experienced appraisers.

In Alberta, many acts in the past provided for three arbitrators. The new Act provides:

Crown-arbitrators unless either party insists on the Court (secs. 19 \& 20).

Municipalities-Public Utilities Board.

Companies and other bodies-Public Utilities Board.

6rR.8.C. 2058 , c 108

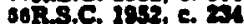

S013, is 416 Geo. 6, c. 12. 
Question No. 20:

Do you see good reason for the different tribunals under the new Act? MR. BROWNLWH: No.

MR. FOOIE: No. I would oppose the use of arbitration procedure in any case. The right of appeal to the Courts on questions of law or jurisdiction should be available.

MR. MACDONAID: My response to Question No. 19 indicates my preference for a single tribunal to deal with all expropriation matters.

PROFESSOR ANGUS: It may be that an arbitrator or Court in Crown expropriations is preferred so as to remove the possibility of suspicion or allegation that the Crown is receiving favoured treatment from a tribunal which it has created and can control. There is some merit in this argument, it seems to me, which can only be dispelled by the establishment of a completely independent and impartial expropriation tribunal.

Question No. 21:

What kind of tribunal is best?

MR. LAYCRAFT (Chairman): It is impossible for anyone who has had the misfortune to appear before arbitrators fixing expropriation compensation to say a good word on their behalf. In practice there is extreme difficulty in getting three arbitrators appointed, since the two appointed by the various parties can seldom agree on the third. During the hearing, each arbitrator who has been appointed by one of the parties feels himself bound to take the party's view, with the result that the hearing develops into a contest for the ear of the independent arbitrator.

PROFESSOR ANGUS: Tribunal membership should include a lawyer to handle procedural problems and an expert in land valuation. In other respects it might follow the precedent of the Right of Intry Arbitration Board ${ }^{00}$ in this Province which has dealt admirably with both Crown and private interests in an expeditious but judicial manner.

MR. BROWNL.FE: I would prefer to see all compensation hearings before our Public Utilities Board or a comparable Board chaired by a lawyer.

MR. MACDONAID: As stated previously, I am of the opinion that the Public Utilities Board would be satisfactory for all expropriation proceedings.

MR. FOOTE: I would favour an impartial tribunal such as the Public Utilities Board, sufficiently staffed with men trained or experienced in the field of expropriation. This Board would delegate its members to hold regular sittings at specified dates throughout the Province so that applications could be dealt with by qualified men efficiently, with dispatch, and at a minimum of cost, inconvenience and delay to the public. 